\title{
PENINGKATAN KETERAMPILAN GENERIK SAINS PADA MATERI TATA SURYA MELALUI PEMBELAJARAN BERBANTUAN APLIKASI SOLAR SYSTEM SCOPE UNTUK SISWA SMP
}

\author{
Ika Mustika Sari' ${ }^{,}$Syifa Fauzi Ahmad ${ }^{1}$ dan Amsor'1
}

\section{Departemen Pendidikan Fisika FPMIPA UPI, Jl. Dr. Setiabudhi 229 Bandung 40154, Jawa Barat \\ E-mail:ikams@upi.edu}

\begin{abstract}
ABSTRAK
Agar mampu bertahan dan meningkatkan kualitas diri di jenjang pendidikan yang lebih tinggi maupun di dunia pekerjaan, diperlukan keterampilan generik sains, yaitu kemahiran yang dapat ditumbuhkan dari pembelajaran sains sebagai bekal meniti karir dalam bidang yang lebih luas. Pada zaman sekarang, banyak hal dapat dilakukan menggunakan gawai, tidak terkecuali pembelajaran fisika. Oleh karena itu, peneliti bermaksud melakukan penelitian yang bertujuan untuk mengetahui perbedaan peningkatan keterampilan generik sains yang signifikan antara kelas yang menerapkan pembelajaran tata surya dengan pendekatan saintifik berbantuan aplikasi Solar System Scope dengan kelas yang tidak menggunakan aplikasi Solar System Scope. Metode yang digunakan pada penelitian ini adalah quasi-experiment dengan desain penelitian control group pretest-posttest design. Sampel penelitian terdiri dari 31 siswa kelas eksperimen dan 31 siswa kelas kontrol pada salah satu SMP Negeri di Kota Bandung. Kedua kelas diberi tes berupa soal pilihan ganda. Hasil analisis data menunjukkan adanya peningkatan keterampilan generik sains pada kedua kelas dengan $\mathrm{N}$-gain 45,9\% pada kelas eksperimen dan 22,8\% pada kelas kontrol. Kesimpulan dari penelitian ini dapat diketahui berdasarkan uji hipotesis Mann Whitney yang menghasilkan nilai zhitung = $-3,60$. Hal ini menunjukkan bahwa terdapat perbedaan peningkatan keterampilan generik sains yang signifikan antara kedua kelas setelah diterapkannya pembelajaran berbantuan aplikasi Solar System Scope.
\end{abstract}

Kata kunci: Keterampilan Generik Sains, Solar System Scope, Tata SUrya

\begin{abstract}
In order to survive and improve self quality in higher levels of education and work, generic science skills are needed. Generic science skill is the skill that can be grown from science learning as a provision to pursue careers in a broader field. In this day and age, many things can be done by using devices, including physics learning. This study aims to find out the differences of generic science skills improvement between a class that apply solar system learning with a scientific approach assisted by Solar System Scope with a class that do not use Solar System Scope. The method used in this study was quasi-experiment with the control group pretestposttest design. The sample consisted of 31 experimental class students and 31 control class students in the junior high school in Bandung. Both classes were given the multiple choice test. The results of data analysis showed an improvement in both classes with $\mathrm{N}$-gain $45.9 \%$ in the experimental class and $22.8 \%$ in the control class. The conclusion of this study can be showed by Mann Whitney hypothesis test which produces $z=-3.60$. It shows that there is a significant differences of generic science skills improvement between both classes after the implementation of solar system learning assisted by Solar System Scope.
\end{abstract}

Keywords: Generic Science Ability, Solar System Scope, Space

DOI: http://dx.doi.org/10.15575/jtlp.v1i2.4294

Received: 2 Maret 2019 ; Accepted: 3 Agustus 2019 ; Published: 19 Agustus 2019 


\section{PENDAHULUAN}

Pembelajaran IPA di jenjang SMP memiliki berbagai karakteristik dan tantangan. Guru diharapkan dapat melaksanakan pembelajaran dengan berbagai cara agar semua siswa tertarik untuk belajar IPA. Namun, di jenjang SMP, siswa belum dikelompokkan berdasarkan bidang yang diminati. Dalam satu kelas, bisa saja terdapat banyak siswa yang tidak akan memilih bidang IPA. Hal ini tentunya menjadikan tantangan sendiri bagi guru IPA di jenjang SMP. Sehingga guru IPA diharapkan mampu menciptakan proses pembelajaran yang mampu membekali siswa dengan keterampilan-keterampilan yang dapat digunakan pada jenjang pendidikan yang lebih tinggi.

Keterampilan atau kemahiran yang dapat ditumbuhkan dari pembelajaran sains sebagai bekal meniti karir dalam bidang yang lebih luas disebut dengan keterampilan generik sains (Brotosiswoyo, 2000:4-5). Artinya, keterampilan generik sains dapat dilatihkan pada jenjang pendidikan tertentu sebagai bekal untuk menempuh pendidikan atau pekerjaan setelah lulus.

Pada jenjang SMP/MTs - yang termasuk tingkat kompetensi pendidikan dasar (Permendikbud Nomor 21 Tahun 2016) sebagian besar siswa akan melanjutkan pendidikan ke jenjang yang lebih tinggi, yaitu SMA/SMK/MA. Semakin tinggi jenjang pendidikan, semakin spesifik kemampuan yang diperlukan. Siswa yang melanjutkan pendidikan ke SMA/MA akan dikerucutkan ke dalam kelas IPA, IPS, dan Bahasa. Sementara itu, siswa yang melanjutkan pendidikan ke SMK akan dikerucutkan ke dalam kejuruan tertentu yang siap untuk bekerja, seperti akuntansi, pertanian, perkantoran, perhotelan, seni, dan lain sebagainya. Dengan demikian, siswa di jenjang SMP perlu mempersiapkan diri dengan cara melatih keterampilan yang dapat menunjang dirinya untuk mengikuti pendidikan selanjutnya. Hal ini sejalan dengan Peraturan Pemerintah Republik Indonesia Nomor 19 Tahun 2005 tentang Standar Nasional Pendidikan Pasal 26 ayat (1) yang menjelaskan bahwa tujuan dari standar kompetensi lulusan pendidikan dasar adalah meletakkan dasar kecerdasan, pengetahuan, kepribadian, ahklak mulia, serta keterampilan untuk hidup mandiri dan mengikuti pendidikan lebih lanjut.

Keterampilan yang dimaksud pada Peraturan Pemerintah Republik Indonesia Nomor 19 Tahun 2005 tentang Standar Nasional Pendidikan Pasal 26 ayat (1) dapat berupa keterampilan generik sains menurut Brotosiswoyo (2000:6-21), yaitu 1) pengamatan langsung; 2) pengamatan tak langsung; 3) kesadaran tentang skala; 4) bahasa simbolik; 5) kerangka logika taatazas; 6) inferensi logika; 7) hukum sebab akibat; 8) pemodelan; dan 9) membangun konsep.

Sembilan keterampilan tersebut tidak hanya dibutuhkan oleh siswa yang melanjutkan pendidikan ke jenjang SMA jurusan IPA. Sebagai contoh, kesadaran tentang skala merupakan keterampilan membandingkan ukuran berbagai objek, seperti besar atau kecil, jauh atau dekat, banyak atau sedikit, cepat atau lambat, dan lain sebagainya. Siswa di jurusan IPS tentu memerlukan keterampilan ini untuk menginterpretasikan peta, sedangkan siswa di jurusan seni musik memerlukan keterampilan ini untuk membedakan tempo dari sebuah lagu. Sehingga pembelajaran IPA yang melatihkan keterampilan generik sains mampu menciptakan proses pembelajaran yang mendekati ideal sebagai bekal untuk meniti karir (Tawil dan Liliasari, 2014:3).

Urgensi dari pembelajaran yang mampu melatihkan keterampilan generik sains sebagaimana telah dijabarkan sebelumnya sejalan dengan keadaan di lapangan. Hasil penelitian yang dilakukan oleh Nurjannah (2014) menunjukkan bahwa secara umum penguasaan kemampuan generik siswa SMP hanya sebesar $56,10 \%$ yang termasuk ke dalam kategori kurang. Artinya, perlu adanya metode atau perlakuan yang tepat dalam proses pembelajaran IPA agar keterampilan generik sains siswa dapat meningkat. 
Untuk melatihkan keterampilan generik sains, perlu diterapkan metode pembelajaran yang sesuai. Pembelajaran yang telah berlangsung selama ini lebih didominasi oleh guru dengan menggunakan metode ceramah. Berdasarkan penelitian sebelumnya, $61,36 \%$ siswa menyebutkan bahwa guru menjelaskan suatu materi pelajaran hanya dengan metode ceramah. Pada perkembangan pendidikan saat ini, metode ceramah cenderung dianggap monoton dan kurang menarik minat siswa. Padahal 81,52\% siswa menyatakan lebih mengerti suatu materi pelajaran jika dijelaskan dengan gambar dibandingkan dengan ceramah saja.

Salah satu materi yang diajarkan pada mata pelajaran IPA di jenjang SMP adalah tata surya. Materi tata surya di jenjang SMP sering kali hanya berupa teori dan hafalan serta disampaikan melalui ceramah. Padahal, topik bahasan pada materi tata surya merupakan objek yang kontekstual. Praktikum atau pengamatan pada materi ini lebih efektif dilakukan pada malam hari karena benda langit dapat lebih mudah dilihat dibanding pada siang hari.

Selain itu, pergerakan benda langit yang dikaji pada materi tata surya cenderung lambat jika diamati secara langsung sehingga membutuhkan waktu yang cukup lama dalam pengamatannya. Contohnya pada materi gerak semu tahunan Matahari, pengamatannya dapat berlangsung selama satu tahun. Namun, waktu belajar di sekolah yang diterapkan di Indonesia hanya berkisar pukul 07.00-16.00, dengan alokasi waktu untuk materi tata surya hanya berkisar 10 jam sehingga sulit untuk melakukan kegiatan pengamatan benda langit secara langsung. Hal tersebut menyebabkan guru lebih banyak menginstruksikan siswa agar membaca sendiri materi tersebut dan lebih fokus ke materi lain yang menggunakan banyak rumus serta memperbanyak latihan soal. Dengan demikian, siswa cenderung menghafal materi. Hal ini terbukti pada penelitian sebelumnya tercatat 73,91\% siswa mempelajari materi tata surya dengan cara menghafal. Padahal, 68,18\% siswa tidak suka materi yang berisi banyak hafalan. Hal ini menjadi kontradiktif dan menimbulkan kecenderungan siswa akan sulit menyukai materi tata surya.

Kemampuan siswa mengenai materi tata surya terlihat pada hasil soal tes sebelumnya yang menunjukkan nilai rata-rata siswa 41,74 (skala 100). Artinya, kurang dari setengah soal tes dapat dijawab dengan benar. Hal ini menunjukkan kurangnya kemampuan siswa pada materi tata surya. Meskipun demikian, dari 10 soal dengan topik pembahasan yang berbeda, sebanyak $87 \%$ siswa mampu menjawab benar pada materi mengenai karakteristik tata surya. Namun pada topik mengenai satelit hanya dijawab benar oleh $9 \%$ siswa.

Salah satu alat yang dapat menunjang kebutuhan pada materi tata surya adalah Solar System Scope, yaitu aplikasi yang dapat dioperasikan pada gawai yang berbasis augmented reality. Pada penelitian sebelumnya, $77,27 \%$ siswa menyatakan dapat mengoperasikan gawai dengan baik, dan $79,35 \%$ siswa menggunakan gawai setiap hari. Hal ini menunjukkan bahwa penggunaan gawai dalam pembelajaran tidak akan memberikan banyak kesulitan secara teknis karena siswa sudah terbiasa mengoperasikannya.

Penggunaan aplikasi pada gawai dapat meningkatkan partisipasi siswa pada proses pembelajaran serta siswa akan memiliki pengalaman belajar dengan konteks yang nyata. Melalui aplikasi Solar System Scope, siswa dapat melakukan pengamatan benda langit dengan mengarahkan gawai ke posisi benda langit yang sesungguhnya pada waktu pengamatan. Waktu dan lokasi pengamatan pada aplikasi dapat diatur sesuai kebutuhan. Dengan demikian, pengamatan dapat dilakukan kapan saja, baik siang maupun malam hari. Kemampuan siswa yang cukup baik dalam mengoperasikan gawai juga memungkinkan siswa untuk melakukan pengamatan secara mandiri di luar kelas. Dengan menggunakan aplikasi ini, siswa juga dapat mengetahui karakteristik benda langit yang diamati. Mulai dari warna, bentuk, jari-jari, periode, sampai strukturnya. 
Solar System Scope merupakan aplikasi yang menampilkan model tata surya yang dapat dieksplorasi oleh penggunanya. Selain itu, terdapat pula informasi mengenai benda langit lainnya di luar tata surya, seperti bintang dan rasi bintang.

Tersedia berbagai fitur pada aplikasi Solar System Scope yang memungkinkan pengguna memperoleh banyak informasi mengenai tata surya, baik melalui pengamatan maupun melalui data yang telah tersedia. Fitur yang tersedia pada aplikasi
Solar System Scope diantaranya Solar System, Planet Explore, Night Sky, dan Near Star.

Fitur Solar System merupakan fitur yang berfungsi sebagai menu utama pada aplikasi ini. Fitur ini memungkinkan pengguna untuk mengeksplorasi tata surya melalui peta langit atau simulasi. Peta ini menampilkan benda langit, yaitu planet, bintang, komet, asteroid, dan rasi bintang berdasarkan keadaan langit pada waktu dan tempat yang tertera di aplikasi yang dapat diubah secara manual.

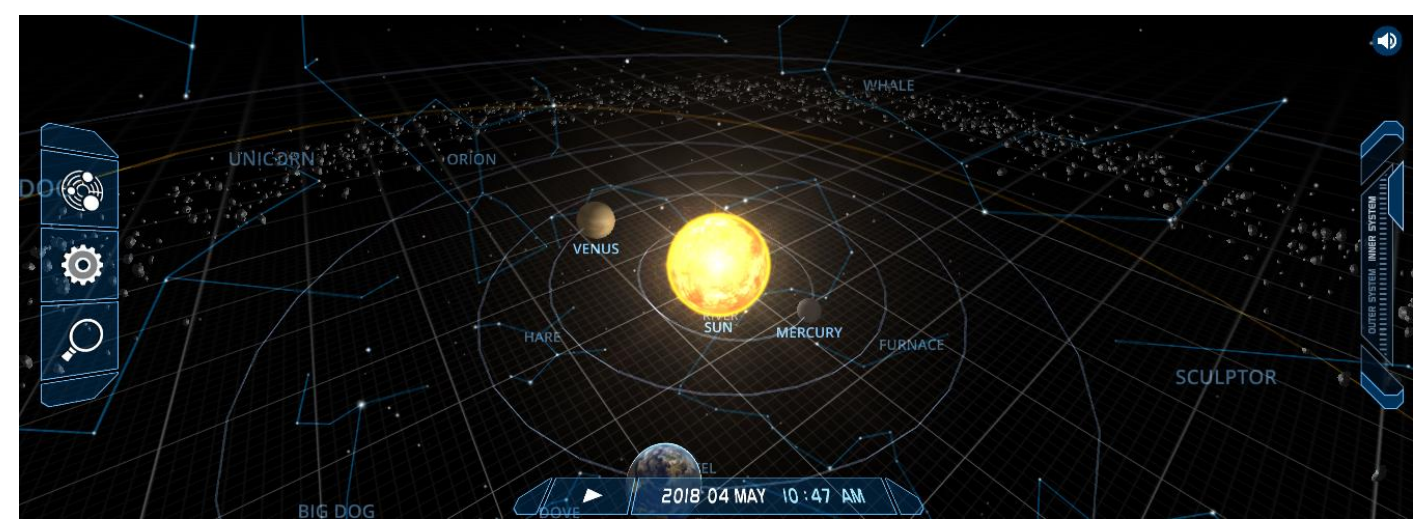

Gambar 1. Peta Langit yang Menampilkan Keadaan Langit Sesuai Waktu yang Tertera serta Lokasi yang dapat Diatur.

Sumber: Aplikasi Solar System Scope

Objek yang ditampilkan pada layar dapat diatur sesuai kebutuhan pada setting. Jika pengguna hanya ingin melihat planet dan bintang tanpa garis orbitnya, dapat diatur di setting. Model tata surya ini juga dapat digunakan sebagai simulasi gerak planet dengan menekan tombol play di bagian bawah tampilan seperti pada Gambar 1 . Simulasi tersebut dapat diatur tanggal, waktu, dan kecepatannya. Dengan demikian, pengguna dapat mengamati rotasi dan revolusi benda langit dengan realistis.

Fitur yang kedua adalah Planet Explore. Pada fitur ini, pengguna dapat memperoleh banyak informasi mengenai delapan planet yang ada di tata surya beserta satelitnya. Selain itu, pengguna juga dapat memperoleh informasi mengenai empat planet kerdil. Ketika pengguna memilih planet atau objek langit mana yang akan dieksplorasi, pengguna akan mendapat pilihan Planet System/Orbit, Encyclopedia, dan Structure. Pada menu Planet System/Orbit, aplikasi akan menampilkan tampilan yang mirip dengan pada peta langit, namun objek dan orbit yang ditampilkan hanya mengenai benda langit yang dipilih saja.

Pada menu Encyclopedia, akan muncul data matematis mengenai objek langit yang sedang diamati, mulai dari massa, diameter, periode, sampai suhu. Selain itu, ada pula informasi mengenai ciri khas, sejarah penemuan, dan berita terbaru dari planet tersebut. 


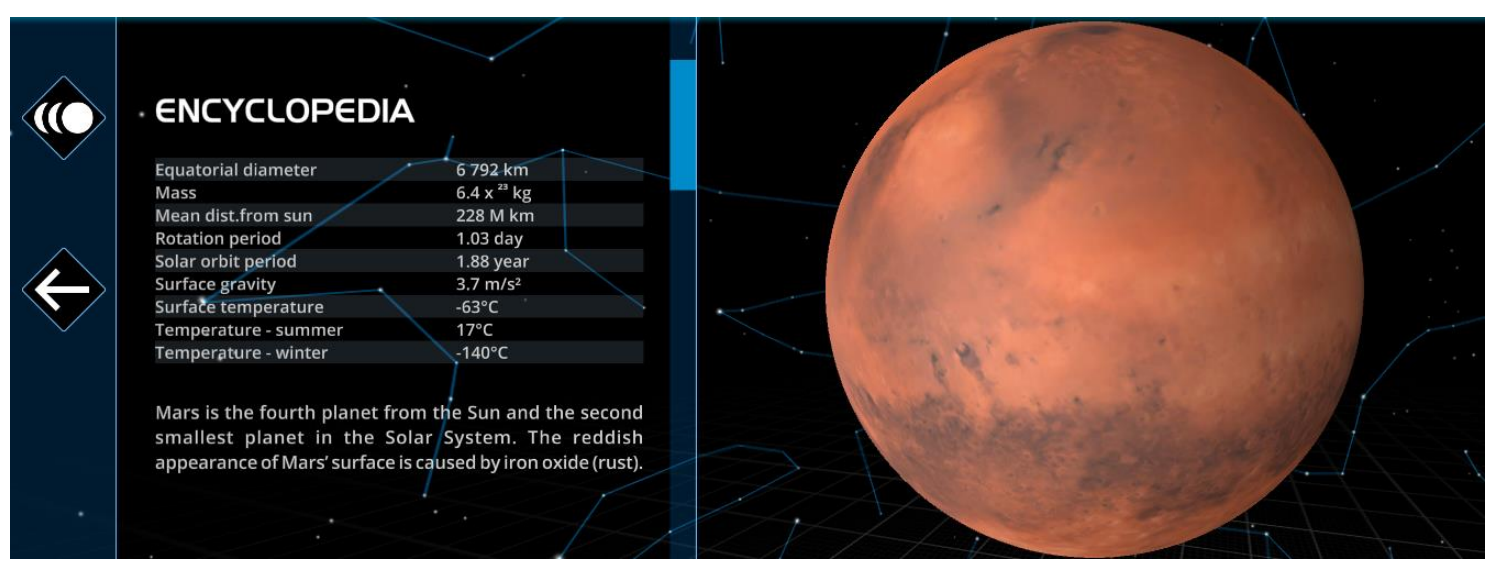

Gambar 2. Menu Encyclopedia yang Menampilkan Data dan Informasi Umum tentang Planet. Sumber: Aplikasi Solar System Scope

Pada menu Structure, pengguna akan memperoleh informasi mengenai struktur atau lapisan beserta komposisi dari objek langit yang diamati secara 3D.

Solar System Scope merupakan salah satu aplikasi astronomi yang memungkinkan penggunanya dapat mengamati benda langit secara augmented reality melalaui fitur selanjutnya, yaitu Night Sky. Artinya, posisi benda langit yang ditunjukkan oleh aplikasi ini merupakan posisi yang sebenarnya pada saat itu. AR (Augmented Reality) pada aplikasi Solar System Scope ini memanfaatkan teknologi GPS (Global Positioning System) atau disebut juga GPS Based Tracking untuk melacak posisi benda langit yang akan diamati. Agar sesuai, pengguna sebelumnya harus mengatur lokasi menjadi Jakarta, Indonesia. Hanya terdapat satu kota di Indonesia pada aplikasi ini. Pengguna juga harus memastikan waktu dan tanggal yang tertera sesuai dengan waktu dan tanggal pengamatan.

Fitur yang terakhir adalah Near Star. Pada fitur ini, pengguna dapat mengamati bintang yang dekat dengan tata surya. Selain dapat mengamati posisi secara langsung, pengguna juga dapat mencari menggunakan fitur Search untuk mengetahui posisi bintang yang ingin diamati.

Berdasarkan paparan masalah di atas, diperlukan suatu media yang dapat membantu proses pembelajaran tata surya secara nyata untuk melatihkan keterampilan generik sains. Dengan fokus pada materi tata surya, aplikasi Solar System Scope diharapkan mampu meningkatkan keterampilan generik sains siswa, terutama keterampilan dalam melakukan pengamatan tak langsung, pemodelan, hukum sebab akibat, dan kesadaran tentang skala. Aplikasi Solar System Scope mampu berperan sebagai multimedia pembelajaran yang melibatkan gambar, data, serta simulasi yang dapat digunakan pada proses pembelajaran di kelas maupun mandiri. Pengoperasian aplikasi ini dapat dilakukan kapan dan dimana saja. Sehingga diharapkan mampu mengatasi masalah yang telah dipaparkan sebelumnya. Oleh karena itu, peneliti memilih masalah ini untuk diteliti melalui penelitian yang berjudul "Peningkatan Keterampilan Generik Sains pada Materi Tata Surya melalui Pembelajaran berbantuan Aplikasi Solar System Scope untuk Siswa SMP".

Berdasarkan judul tersebut, rumusan masalah yang digunakan pada penelitian ini adalah "Apakah terdapat perbedaan peningkatan keterampilan generik sains yang signifikan antara kelas kelas yang menerapkan pembelajaran tata surya dengan pendekatan saintifik berbantuan aplikasi Solar System Scope dengan kelas yang menerapkan pembelajaran tata surya dengan pendekatan saintifik tanpa menggunakan aplikasi Solar System Scope?". Rumusan masalah tersebut dapat diuraikan menjadi pertanyaan penelitian sebagai berikut.

1. Bagaimana implementasi dari pembelajaran berbantuan aplikasi Solar System Scope pada materi tata surya untuk siswa SMP?

2. Bagaimana peningkatan setiap aspek keterampilan generik sains setelah diterapkan pembelajaran berbantuan aplikasi Solar System Scope pada materi tata surya untuk siswa SMP? 
Berdasarkan rumusan masalah, tujuan penelitian ini adalah untuk mengetahui adakah perbedaan peningkatan keterampilan generik sains antara kelas yang menerapkan pembelajaran tata surya dengan pendekatan saintifik berbantuan aplikasi Solar System Scope dengan kelas yang menerapkan pembelajaran tata surya dengan pendekatan saintifik tanpa menggunakan aplikasi Solar System Scope.

\section{METODE}

Penelian ini dilakukan menggunakan metode penelitian quasi-experiment. Pada penelitian ini subyek penelitian terdiri dari satu kelas eksperimen dan satu kelas kontrol. Penelitian ini bertujuan untuk mengetahui bagaimana peningkatan keterampilan generik sains siswa setelah diterapkan pembelajaran dengan berbantuan aplikasi Solar System Scope. Berdasarkan tujuan tersebut, maka perlu adanya kelas kontrol atau kelas pembanding. Penyebaran siswa di sekolah lokasi penelitian menggunakan sistem acak sehingga kelas eksperimen dapat dibandingkan dengan kelas kontrol.

Pada penelitian ini, kelas eksperimen diberikan perlakuan yang berbeda dengan kelas kontrol. Pada awal pertemuan pembelajaran, peserta didik pada kelas eksperimen diberikan pretest, kemudian diberikan perlakuan (treatment), dan diakhiri dengan posttest. Hasil pretest dan posttest kemudian dibandingkan untuk melihat peningkatan yang terjadi. Selain itu hasil pada kedua kelas juga akan dibandingkan satu sama lain.

Desain penelitian yang digunakan dalam penelitian ini adalah control group pretestposttest design (Arikunto, 2010:125) yang dapat dijelaskan melalui tabel berikut.

Tabel 1. Desain Penelitian dengan Dua Kelas

\begin{tabular}{llll}
\hline Eksperimen & $\mathrm{O}_{1}$ & $\mathrm{X}$ & $\mathrm{O}_{2}$ \\
Kontrol & $\mathrm{O}_{3}$ & $\mathrm{X}$ & $\mathrm{O}_{4}$ \\
\hline
\end{tabular}

Keterangan:

$\mathrm{O}_{1}, \mathrm{O}_{3} \quad$ : Tes awal (pretest)

$\mathrm{X} \quad$ : Perlakuan (treatment)

$\mathrm{O}_{2}, \mathrm{O}_{4} \quad$ : Tes akhir (posttest)
Melalui desain ini, peningkatan keterampilan generik sains siswa pada materi tata surya dapat dilihat dari hasil pretest dan posttest. Selain itu akan dibandingkan pula hasil pada kelas eksperimen dengan hasil pada kelas kontrol.

Partisipan pada penelitian ini adalah 62 orang siswa kelas VII di salah satu SMP Negeri di Kota Bandung. Partisipan tersebut terbagi menjadi dua kelas, yaitu kelas kontrol yang terdiri dari 31 orang siswa dan kelas eksperimen yang terdiri dari 31 orang siswa.

Populasi yang digunakan pada penelitian ini adalah seluruh kelas VII di salah satu SMP Negeri di Kota Bandung. Sedangkan sampel pada penelitian ini adalah dua kelas VII dengan satu kelas sebagai kelas kontrol dan satu kelas lainnya sebagai kelas eksperimen. Sampel ini dipilih dengan menggunakan teknik convenience sampling (Sugiyono, 2012). Hal ini disebabkan penyebaran kelas di sekolah tersebut dilakukan secara acak, tidak berurutan berdasarkan nilai, serta tidak ada kelas unggulan. Sehingga dapat diasumsikan semua kelas dalam jenjang yang sama memiliki kemampuan yang sama. Selain itu, pemilihan kedua kelas ini ditentukan berdasarkan jadwal pelajaran yang tidak bersamaan.

Aspek keterampilan generik sains yang diukur pada penelitian ini adalah pemodelan, pengamatan tak langsung, kesadaran tentang skala, dan hukum sebab akibat. Keempat aspek tersebut diukur menggunakan instrumen berbentuk tes. Instrumen tes terdiri dari 24 butir soal pilihan ganda. Soal tersebut terdiri dari beberapa sub materi pokok, yaitu sistem tata surya, Matahari sebagai bintang, karakteristik planet serta satelit alami penyusunnya, dan Hukum Kepler.

Pada penelitian ini, peneliti membuat hipotesis nol (Ho) dan hipotesis kerja (Ha) sebagai berikut.

Ho: Tidak terdapat perbedaan keterampilan pemodelan yang signifikan antara kelas eksperimen dengan kelas kontrol setelah diterapkannya pembelajaran berbantuan aplikasi Solar System Scope. 
Ha: Terdapat perbedaan keterampilan pemodelan yang signifikan antara kelas eksperimen dengan kelas kontrol setelah diterapkannya pembelajaran berbantuan aplikasi Solar System Scope.

Hipotesis tersebut diuji menggunakan uji Mann Whitney terhadap N-gain pada kedua kelas. Pengolahan data yang dilakukan pada penelitian ini terdiri atas beberapa bagian, yaitu indeks gain yang dinormalisasi, uji homogenitas, uji normalitas, serta uji hipotesis.

Selain instrumen tes, terdapat instrumen nontes yang digunakan pada penelitian ini. Instrumen non-tes yang digunakan adalah angket ketertarikan siswa dalam penggunaan aplikasi Solar System Scope pada materi tata surya. Tujuan angket ini adalah untuk mengetahui tanggapan siswa terhadap penggunaan aplikasi Solar System Scope di kelas. Angket dibuat dalam skala likert yang dinyatakan dalam empat pilihan, yaitu sangat setuju, setuju, tidak setuju, dan sangat tidak setuju. Terdapat 13 pernyataan yang berkaitan dengan penggunaan aplikasi Solar System Scope pada materi tata surya dalam angket ini.

\section{HASIL DAN PEMBAHASAN}

Pada penelitian ini, fokus utama peneliti adalah untuk mengetahui perbedaan peningkatan keterampilan generik sains siswa pada materi tata surya antara siswa pada kelas yang diberi treatment berupa pembelajaran dengan berbantuan aplikasi Solar System Scope dengan siswa pada kelas yang tidak diberi treatment berupa pembelajaran dengan berbantuan aplikasi Solar System Scope. Sebelum dan sesudah dilakukan treatment, siswa pada kelas eksperimen maupun kelas kontrol mengerjakan soal tes yang terdiri dari 24 butir soal pilihan ganda. Secara keseluruhan, hasil tes keterampilan generik sains siswa beserta $N$ gain pada kelas eksperimen dan kontrol dapat dilihat pada Tabel 2.

Tabel 2. Nilai Rata-Rata N-Gain Keterampilan Generik Sains

\begin{tabular}{lcc}
\hline & Kelas Eksperimen & Kelas Kontrol \\
Nilai Rata-Rata Pretest & 64,5 & 62,8 \\
Nilai Rata-Rata Posttest & 80,8 & 71,3 \\
Nilai Ideal & 100 & 100 \\
N-Gain (\%) & 45,9 & 22,8 \\
Kategori & Sedang & Rendah \\
\hline
\end{tabular}

Dari hasil yang tertera pada Tabel 2, terlihat perbedaan nilai antara kelas eksperimen dengan kelas kontrol yang dapat digambarkan dalam Gambar 3.

\section{- Kelas Eksperimen $\quad$ Kelas Kontrol}

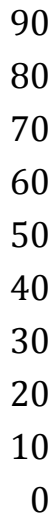

0

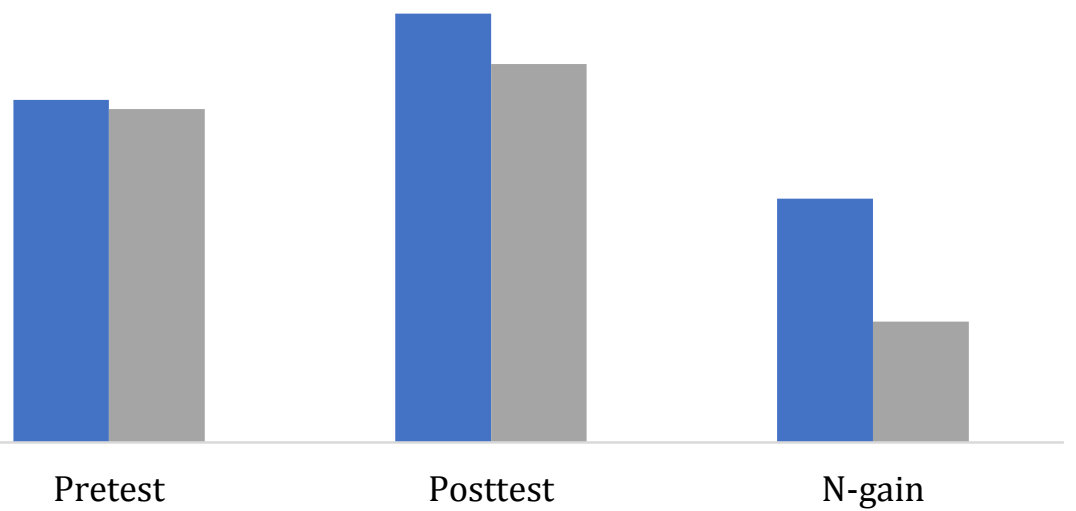

Gambar 3 Perbandingan Nilai Hasil Tes pada Kelas Eksperimen dan Kontrol 
Berdasarkan hasil tes yang terdapat pada Tabel 2 dan Gambar 3, keterampilan generik sains siswa pada kedua kelas mengalami peningkatan. Pada hasil pretest, perbedaan antara kelas eksperimen dan kelas kontrol tidak terlalu jauh. Kelas eksperimen memperoleh persentase nilai rata-rata 64,5, sedangkan kelas kontrol 62,8. Hal ini menunjukkan bahwa pengetahuan awal siswa di kedua kelas tidak memiliki perbedaan yang terlalu jauh. Meskipun demikian, terlihat bahwa kelas eksperimen yang telah diberikan treatment berupa pembelajaran dengan berbantuan aplikasi Solar System Scope mengalami peningkatan yang lebih besar dibandingkan dengan kelas kontrol. Hal ini dibuktikan dengan nilai Ngain yang lebih besar, yaitu $45,9 \%$ dan termasuk kategori sedang. Sementara itu, kelas kontrol hanya menunjukkan N-gain sebesar 22,8\% sehingga termasuk kategori rendah. Hal ini membuktikan bahwa penggunaan aplikasi pada gawai - dalam hal ini Solar System Scope - dapat memberikan dampak positif terhadap peningkatan kemampuan siswa (Purba, 2017).

Sub materi yang diukur pada penelitian ini adalah sistem tata surya, Matahari sebagai bintang, planet, satelit alami, serta Hukum Kepler. Sub materi ini dipilih karena merupakan bahasan yang cocok untuk melatihkan keterampilan generik sains melalui pembelajaran berbantuan aplikasi Solar System Scope.

Peningkatan keterampilan generik sains dapat diketahui melalui perhitungan N-gain. Namun, peneliti juga melakukan beberapa uji statistik untuk mengetahui kondisi data yang diperoleh. Uji pertama yang dilakukan adalah uji normalitas. Variabel yang diukur pada penelitian ini adalah perbedaan peningkatan keterampilan generik sains antara kelas eksperimen dengan kelas kontrol. Peningkatan tersebut dapat diketahui dari N-gain. Sehingga uji normalitas dilakukan terhadap dua kelompok data, yaitu N-gain kelas eksperimen dan N-gain kelas kontrol. Hasil uji normalitas menunjukkan bahwa kedua data tidak terdistribusi normal. Setelah uji normalitas, uji selanjutnya yang dilakukan adalah uji homogenitas. Seperti halnya uji normalitas, uji homogenitas juga dilakukan terhadap N-gain pada kelas eksperimen dan kontrol. Hasil perhitungan menunjukkan bahwa kedua kelas merupakan sampel yang homogen. Setelah diketahui bahwa data tidak terdistribusi normal namun homogen, peneliti memutuskan untuk menggunakan uji Mann Whitney untuk menguji hipotesis penelitian. Hasil uji statistik data penelitian dapat dijelaskan pada Tabel 3.

Tabel 3. Hasil Uji Statistik Data Penelitian

\begin{tabular}{lcc}
\hline \multicolumn{1}{c}{ Jenis Uji Statistik } & Hasil & Kesimpulan \\
$\begin{array}{l}\text { Uji Normalitas Kelas } \\
\text { Eksperimen }\end{array}$ & $\chi^{2}{ }_{\text {hitung }}=173,427<\chi^{2}{ }_{\text {tabel }}=50,892$ & Tidak Normal \\
\hline $\begin{array}{l}\text { Uji Normalitas Kelas } \\
\text { Kontrol }\end{array}$ & $\chi^{2}{ }_{\text {hitung }}=437,783<\chi^{2}{ }_{\text {tabel }}=50,892$ & Tidak Normal \\
\hline Uji Homogenitas & $F_{\text {hitung }}=1,14<F_{\text {tabel }}=1,84$ & Homogen \\
\hline $\begin{array}{l}\text { Uji Hipotesis Mann } \\
\text { Whitney }\end{array}$ & $z_{\text {hitung }}=-3,60$ & \multirow{2}{*}{ Hipotesis Kerja Diterima } \\
\hline
\end{tabular}

Tabel 3 membuktikan bahwa data penelitian tidak terdistribusi normal, homogen, serta hipotesis kerja diterima. Artinya, dapat dipastikan bahwa terdapat perbedaan peningkatan keterampilan generik sains yang signifikan antara kelas eksperimen dengan kelas kontrol setelah diterapkannya pembelajaran berbantuan aplikasi Solar System Scope. Hal ini juga didukung dengan keterlaksanaan pembelajaran yang berlangsung sangat baik sebagaimana yang ditunjukkan pada Tabel 2. Proses pembelajaran yang telah berlangsung disusun berdasarkan tahapan pembelajaran berbasis aplikasi pada gawai yang telah dilakukan Purba (2017). Tahapan tersebut terdiri dari (1) siswa mengunduh aplikasi pembelajaran pada gawai masing-masing; (2) guru menjelaskan tujuan dan tata cara penggunaan aplikasi pembelajaran; (3) siswa dibagi dalam kelompok-kelompok belajar; (4) siswa mengakses aplikasi 
pembelajaran untuk memperoleh informasi tertentu berdasarkan tujuan pembelajaran; dan (5) siswa berdiskusi dalam kelompok.

Terdapat empat aspek keterampilan generik sains yang dilatihkan serta diukur pada penelitian ini, yaitu pemodelan, pengamatan tak langsung, kesadaran tentang skala, dan hukum sebab akibat. Keempatnya diukur menggunakan instrumen tes pilihan ganda yang terdiri dari 24 butir soal, 4 soal mengukur pemodelan, 12 soal mengukur pengamatan tak langsung, 4 soal mengukur kesadaran tentang skala, serta 4 soal mengukur hukum sebab akibat. Persentase $\mathrm{N}$-gain untuk setiap aspek dapat ditampilkan secara umum oleh Tabel 4.

Tabel 4. Persentase N-Gain Setiap Aspek Keterampilan Generik Sains

\begin{tabular}{|c|c|c|c|c|c|c|}
\hline & \multirow{2}{*}{$\begin{array}{l}\text { Nilai } \\
\text { Ideal }\end{array}$} & \multicolumn{2}{|c|}{ Nilai Rata-Rata } & \multirow{2}{*}{$\begin{array}{c}\text { N-gain } \\
(\%)\end{array}$} & \multirow{2}{*}{ Kategori } \\
\hline & & & Pretest & Posttest & & \\
\hline \multirow{4}{*}{$\begin{array}{c}\text { Kelas } \\
\text { Eksperimen }\end{array}$} & Pemodelan & 100 & 37,0 & 85,5 & 77,0 & Tinggi \\
\hline & $\begin{array}{l}\text { Pengamatan Tak } \\
\text { Langsung }\end{array}$ & 100 & 79,0 & 88,8 & 46,7 & Sedang \\
\hline & $\begin{array}{c}\text { Kesadaran Tentang } \\
\text { Skala }\end{array}$ & 100 & 75,0 & 85,5 & 42,0 & Sedang \\
\hline & Hukum Sebab Akibat & 100 & 38,0 & 47,5 & 15,3 & Rendah \\
\hline \multirow{4}{*}{ Kelas Kontrol } & Pemodelan & 100 & 41,3 & 59,8 & 31,5 & Sedang \\
\hline & $\begin{array}{l}\text { Pengamatan Tak } \\
\text { Langsung }\end{array}$ & 100 & 76,1 & 81,4 & 22,2 & Rendah \\
\hline & $\begin{array}{c}\text { Kesadaran Tentang } \\
\text { Skala }\end{array}$ & 100 & 71,8 & 87,0 & 53,9 & Sedang \\
\hline & Hukum Sebab Akibat & 100 & 35,5 & 36,3 & 1,2 & Rendah \\
\hline
\end{tabular}

Secara keseluruhan, keempat keterampilan generik sains di dua kelas mengalami peningkatan. Hal itu terbukti dengan $\mathrm{N}$-gain keseluruhan yang diperoleh. Kelas eksperimen memperoleh $\mathrm{N}$-gain 45,9\% dengan kategori sedang, dan kelas kontrol memperloeh N-gain 22,8\% dengan kategori

Kelas Eksperimen rendah. Namun, keempat aspek tersebut meningkat dengan $\mathrm{N}$-gain yang berbedabeda di kedua kelas. Ada aspek yang mengalami peningkatan pesat adapula yang hanya sedikit meningkat. Hasil tes pada setiap aspek di kedua kelas dapat digambarkan pada Gambar 4.

Kelas Kontrol

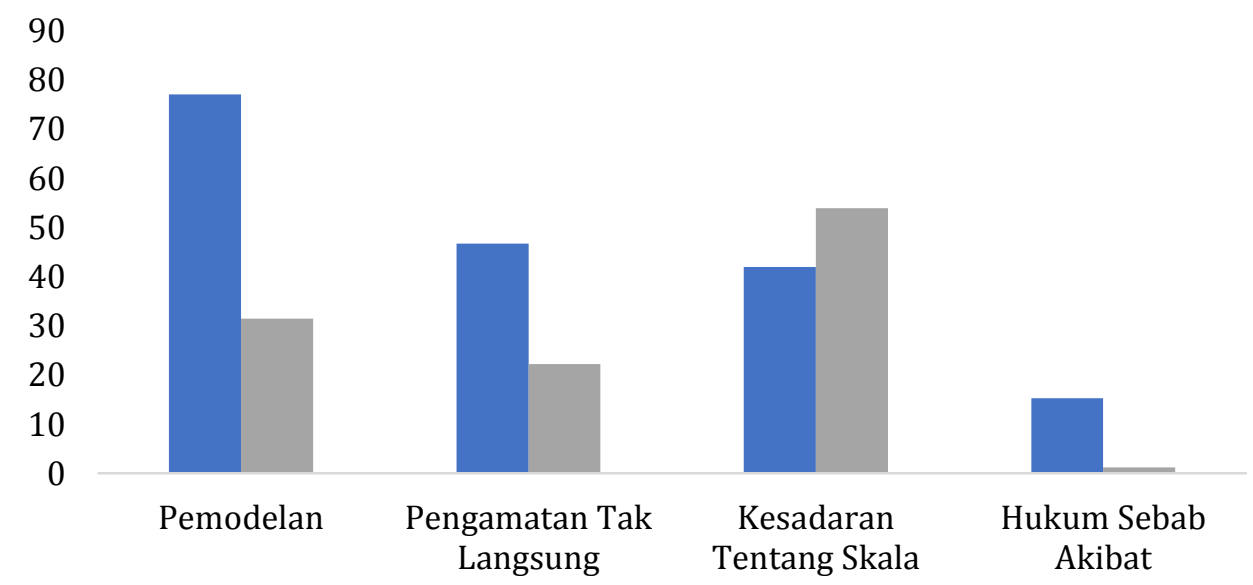

Gambar 4. Perbandingan $N$-Gain untuk Setiap Aspek Keterampilan Generik Sains pada Kelas Eksperimen dan Kontrol

Pada Gambar 4 terlihat bahwa peningkatan paling tinggi terdapat pada aspek pemodelan di kelas eksperimen dengan $\mathrm{N}$ gain sebesar 77,0\% dan termasuk kategori tinggi. Sedangkan peningkatan paling rendah terdapat pada aspek hukum sebab akibat di kelas kontrol dengan N-gain 1,2\%. Hasil tes kelas eksperimen pada aspek 
pemodelan, pengamatan tak langsung, dan hukum sebab akibat selalu lebih unggul dibandingkan dengan kelas kontrol. Namun, pada aspek kesadaran tentang skala, kelas kontrol memperoleh N-gain yang lebih besar dibandingkan dengan kelas eksperimen. Bahkan, aspek kesadaran tentang skala merupakan aspek yang mengalami peningkatan paling pesat di kelas kontrol dengan N-gain 53,9\%. Pada penelitian ini, analisis dilakukan pula terhadap setiap aspek keterampilan generik sains yang diukur.

\section{Pemodelan}

Keterampilan pemodelan ini dujikan dengan soal tes yang menggunakan gambar. Hal ini sejalan dengan pendapat Chen et al. (2016) yang menyatakan bahwa pemodelan memungkinkan siswa untuk memvisualisasi konsep ke dalam gambar atau simulasi. Pada penelitian ini, aplikasi Solar System Scope berperan sebagai multimedia pembelajaran yang dapat menampilkan gambar, simulasi, dan tulisan. Dengan demikian, aspek pemodelan dapat dilatihkan menggunakan aplikasi Solar System Scope. Aspek pemodelan diukur menggunakan tiga soal mengenai bentuk orbit planet, dan satu soal mengenai lapisan planet.

Aspek pemodelan diukur menggunakan empat indikator soal yang terdapat pada soal nomor 1, 13, 20, dan 21. Indikator soal nomor 1 adalah pemodelan untuk menunjukkan lintasan revolusi Bumi. Di kelas ekpserimen, bahasan mengenai sub materi ini dibahas menggunakan aplikasi Solar System Scope yang diakses pada gawai siswa. Sementara itu, di kelas kontrol, bentuk orbit revolusi planet dijelaskan menggunakan aplikasi Solar System 3D Simulator yang hanya ditampilkan di depan kelas menggunakan projector.

Lebih lanjut mengenai bentuk orbit revolusi planet, telah dilakukan pula simulasi orbit planet pada bahasan Hukum Kepler di kedua kelas. Simulasi ini mengharuskan siswa menggambar bentuk orbit planet menggunakan benang dan paku mading yang disediakan. Pada pelaksanaannya, seluruh siswa telah mampu menggambar dengan benar dan mampu membedakan elips dengan lingkaran. Namun, siswa belum memahami bentuk orbit planet yang sesungguhnya tidak terlalu elips. Siswa di kelas eksperimen telah lebih memahami hal tersebut dibandingkan kelas kontrol, karena orbit planet yang ditampilkan di aplikasi Solar System Scope tidak terlalu elips, mirip lingkaran, namun Matahari tidak berada tepat di tengah. Dengan demikian, lebih banyak siswa di kelas eksperimen yang mampu mencapai indikator soal nomor 1 dibandingkan dengan siswa di kelas kontrol. Hal ini pula yang menyebabkan siswa di kelas eksperimen lebih unggul dibanding kelas kontrol pada soal indikator nomor 20 dan 21 mengenai Hukum Kepler.

Indikator soal nomor 13 membahas mengenai lapisan planet. Siswa diminta untuk menentukan planet mana yang memiliki lapisan yang mirip dengan Bumi. Materi ini telah dibahas dengan rinci di kelas eksperimen menggunakan aplikasi Solar System Scope untuk melengkapi LKS mengenai karakteristik planet. Siswa di kelas kontrol juga melakukan aktivitas yang sama, yaitu berdiskusi kelompok untuk melengkapi LKS karakteristik planet. Namun, media yang digunakan sebagai sumber data adalah mesin pencari online, sehingga jawabannya lebih beragam dan kompleks.

Meskipun kedua kelas memperoleh $N$-gain keseluruhan yang cukup baik pada aspek pemodelan seperti pada Tabel 5, namun, kelas eksperimen memiliki $\mathrm{N}$-gain yang lebih besar dibandingkan dengan kelas kontrol. Hal ini sesuai dengan pendapat Weintrop et al. (2015) yang menjelaskan bahwa pemodelan menggunakan komputer yang mendemonstrasikan daerah atau fenomena yang spesifik dapat sama kuatnya dengan alat pembelajaran. Siswa di kelas eksperimen dilatihkan keterampilan pemodelan menggunakan aplikasi Solar System Scope yang menampilkan gambar gerak dan karakteristik planet. Dengan demikian, siswa lebih mampu memodelkan bentuk orbit planet dan lapisan planet. Orbit planet terdapat pada menu utama di aplikasi Solar System Scope, sedangkan lapisan planet terdapat pada fitur structure. 


\section{Pengamatan Tak Langsung}

Pengamatan tak langsung merupakan pengamatan yang dilakukan menggunakan alat ukur atau alat bantu lainnya karena keterbatasan alat indera manusia dalam melakukan pengamatan langsung. Pada penelitian ini, aplikasi Solar System Scope dimanfaatkan sebagai alat bantu dalam melakukan pengamatan benda langit.

Terdapat banyak fenomena astronomi serta karakteristik benda langit yang dapat diamati dengan memanfaatkan fitur-fitur pada aplikasi Solar System Scope. Hal inilah yang menyebabkan indikator soal mengenai aspek pengamatan tak langsung memiliki porsi yang lebih banyak dibanding soal lainnya, yaitu sebanyak 50\% atau 12 butir soal dari total 24 butir soal. Aspek pengamatan tak langsung diukur menggunakan satu indikator soal mengenai sistem tata surya, delapan mengenai planet, dan dua mengenai satelit alami. Terdapat empat butir soal yang memiliki indikator yang sama pada aspek ini, yaitu soal nomor 9, 10, 12, dan 14 mengenai planet. Keempat soal tersebut digunakan untuk mengukur indikator soal pengamatan tak langsung untuk mengidentifikasi planet berdasarkan karakteristiknya. Hal ini disebabkan banyaknya cakupan materi yang dapat diukur dengan indikator ini.

Secara keseluruhan, aspek pengamatan tak langsung pada kelas eksperimen memperoleh N-gain yang lebih besar dibandingkan dengan kelas kontrol, yaitu $46,7 \%$ dengan kategori sedang. Sementara kelas kontrol hanya memperoleh $\mathrm{N}$-gain $22,2 \%$ dengan kategori rendah. Hal ini disebabkan ketika kegiatan diskusi kelompok mengenai karakteristik planet, waktu yang tersedia tidak cukup untuk melengkapi LKS di kelas. Sehingga sebagian besar siswa melanjutkan kegiatan tersebut secara mandiri di rumah dan dilanjutkan di pertemuan berikutnya. Materi mengenai satelit alami juga terdapat pada LKS mengenai karakteristik planet. Namun, pada pertemuan berikutnya ternyata masih banyak siswa yang belum selesai mengisi LKS tersebut. Artinya, pengisian LKS karakteristik planet tidak terlaksana secara maksimal di sekolah. Sehingga banyak siswa yang belum paham materi karakteristik planet meskipun telah dibantu aplikasi Solar System Scope.

Fitur yang paling sering digunakan untuk melatihkan keterampilan pengamatan tak langsung adalah night sky. Melalui night sky, siswa dapat melihat planet serta bintang pada waktu dan tempat yang sebenarnya. Selain itu, siswa juga dapat mengamati permukaan dan bentuk benda langit. Sedangkan siswa pada kelas kontrol hanya menggunakan daya ingatnya ketika melakukan pengamatan langsung pada malam hari yang kemudian dibahas ketika proses pembelajaran di kelas. Hasil peningkatan pada kelas eksperimen sejalan dengan penelitian yang telah dilaksanakan Yulianti (2016) yang juga menggunakan media virtual untuk meningkatkan keterampilan generik sains. Siswa dengan pembelajaran menggunakan media virtual mengalami peningkatan keterampilan pengamatan tak langsung dalam kategori sedang ( $N$-gain: 53\%) karena termasuk keterampilan yang tidak sulit dikuasai. Hasil dari penelitian Yulianti ini dapat dijadikan acuan karena menggunakan media pembelajaran virtual yang serupa dengan aplikasi Solar System Scope sebagai media pembelajaran.

\section{Kesadaran Tentang Skala}

Kesadaran tentang skala yang dilatihkan serta diukur pada penelitian ini berkaitan dengan alasan Matahari terlihat besar, urutan planet berdasarkan jarak dari Matahari dan kala revolusi, serta kala revolusi Bulan.

Berdasarkan Tabel 5, terlihat bahwa kelas kontrol mengalami memperoleh $\mathrm{N}$-gain yang lebih besar dibandingkan kelas eksperimen yaitu sebesar 53,9\%. Sementara kelas eksperimen memperoleh $\mathrm{N}$-gain sebesar 42,0\%. Aspek kesadaran tentang skala merupakan satu-satunya aspek yang memiliki N-gain kelas kontrol lebih besar dibandingkan dengan kelas eksperimen.

Bahasan mengenai Matahari sebagai bintang di kelas eksperimen dijelaskan 
menggunakan tampilan pada menu utama aplikasi Solar System Scope. Tampilan tersebut dapat diperbesar sehingga siswa dapat melihat permukaan Matahari dengan lebih jelas dan dapat pula diperkecil sehingga siswa dapat melihat tata surya secara keseluruhan maupun melihat galaksi selain bimasakti. Dengan demikian, siswa dapat membandingkan jarak Bumi tempat manusia tinggal dengan Matahari serta dengan bintang lainnya yang ada di alam semesta. Kegiatan ini juga dibantu dengan pengamatan tak langsung menggunakan fitur night sky yang dapat digunakan untuk mencari objek yang ingin diketahui, diantaranya bintang. Tujuan akhir dari kegiatan ini adalah agar siswa dapat menyimpulkan bahwa Matahari adalah bintang yang paling dekat dengan Bumi. Sementara itu, di kelas kontrol, sub materi ini dibahas secara verbal dan dikuatkan dengan pengetahuan awal siswa mengenai jarak Bumi dengan Matahari.

Bahasan lainnya yang digunakan untuk mengukur kesadaran akan skala adalah mengurutkan planet. Pada kelas eksperimen, keterampilan ini dilatihkan melalui tampilan pada menu utama aplikasi Solar System Scope. Sedangkan pada kelas kontrol, keterampilan ini dilatihkan secara verbal.

Terdapat nilai $N$-gain keterampilan kesadaran tentang skala secara keseluruhan yang lebih besar pada kelas kontrol, yaitu sebesar 53,9\% dibandingkan kelas eksperimen dengan $\mathrm{N}$-gain sebesar 42,0\%. Keduanya termasuk kategori sedang. Hal ini sejalan dengan penelitian yang telah dilakukan Saprudin et al. (2010) terhadap kelas yang telah diberikan perlakuan berupa pembelajaran dengan menggunakan multimedia. Pada penelitian tersebut, keterampilan generik sains kesadaran tentang skala mengalami peningkatan dengan $\mathrm{N}$-gain sebesar $46 \%$ dan termasuk kategori sedang. Pada penelitian ini, $N$-gain pada kelas kontrol lebih besar dibandingkan dengan kelas eksperimen. Hal itu disebabkan banyak siswa yang memiliki kemampuan awal baik, kemudian ketika kegiatan kelompok mereka mengajari teman sekelompoknya. Siswa pada kelas kontrol cenderung lebih banyak berkomunikasi dengan temannya dibandingkan dengan siswa di kelas eksperimen. Dengan demikian, kemungkinan transfer ilmu pengetahuan antar teman lebih besar terjadi di kelas kontrol.

\section{Hukum Sebab Akibat}

Keterampilan generik sains terakhir yang diukur dan dilatihkan adalah hukum sebab akibat. Terdapat empat butir soal yang digunakan untuk mengukur aspek hukum sebab akibat siswa, satu soal mengenai periode rotasi Bumi dan tiga soal mengenai Hukum Kepler. Secara keseluruhan, peningkatan aspek hukum sebab akibat pada kedua kelas hanya termasuk kategori rendah.

Dari data pada Tabel 5 terlihat bahwa peningkatan yang terjadi pada aspek hukum sebab akibat tidak terlalu besar. $N$-gain kelas eksperimen pada aspek hukum sebab akibat adalah 15,3\% sedangkan kelas kontrol 1,2\%. Keduanya termasuk kategori rendah. Hal ini serupa dengan penelitian yang dilakukan Farid dan Leny (2016) terhadap siswa yang diberi perlakuan berupa pembelajaran berbantuan multimedia interaktif. Pada penelitian yang dilakukan Farid, $\mathrm{N}$-gain pada aspek hukum sebab akibat adalah 0,26 yang juga termasuk kategori rendah karena memerlukan kemampuan berpikir yang lebih tinggi.

Materi mengenai periode rotasi Bumi tidak dijelaskan secara gamblang, melainkan hanya berupa stimulus berapa lama waktu yang dibutuhkan Bumi untuk berotasi dan berevolusi satu putaran penuh serta bagaimana geraknya. Artinya, kemampuan berhitung siswa bergantung pada kemampuan individual siswa sejak awal. Sehingga nilai yang lebih besar bisa terdapat di kelas eksperimen maupun kontrol, keduanya memiliki peluang yang sama. Dalam hal ini, nilai pada kelas kontrol lebih besar dibandingkan dengan kelas eksperimen. Bahasan lainnya untuk mengukur aspek hukum sebab akibat adalah Hukum Kepler yang dipecah menjadi tiga butir soal. Nilai siswa di kelas eksperimen 
pada ketiga soal tersebut lebih besar dibandingkan dengan kelas kontrol.

Pada kelas eksperimen, pengamatan mengenai gerak planet dan bentuk orbit dilakukan dengan berbantuan menu utama atau fitur Solar System pada aplikasi Solar System Scope. Siswa dapat mengamati bahwa bentuk orbit bukanlah lingkaran sempurna. Selain itu, siswa juga dapat mengamati gerak revolusi dan rotasi planet pada sistem tata surya dengan kecepatan yang dapat diatur. Sedangkan aktivitas lainnya pada bahasan Hukum Kepler untuk kedua kelas cenderung sama. Siswa menggambar menggunakan styrofoam, paku mading, dan benang untuk menjelaskan Hukum I Kepler, siswa menonton video Hukum II Kepler, serta siswa mengamati tabel data planet untuk Hukum III Kepler.

Dari pembahasan di atas dapat disimpulkan bahwa aspek pemodelan, pengamatan tak langsung, kesadaran tentang skala, serta hukum sebab akibat mengalami peningkatan. Namun, perbedaan peningkatan antara kelas eksperimen dengan kelas kontrol terlihat jelas pada aspek pemodelan dan pengamatan tak langsung. N-gain pemodelan pada kelas eksperimen termasuk kategori tinggi, sedangkan kelas kontrol sedang, serta Ngain pengamatan tak langsung pada kelas eksperimen pada kelas eksperimen termasuk kategori sedang, sedangkan kelas kontrol rendah. Kesadaran tentang skala pada kedua kelas termasuk kategori sedang. Namun, aspek kesadaran tentang skala mengalami peningkatan yang lebih besar pada kelas kontrol dibandingkan dengan kelas eksperimen. Sementara itu, hukum sebab akibat pada kedua kelas termasuk kategori rendah.

Dengan demikian, dapat disimpulkan bahwa pembelajaran berbantuan aplikasi Solar
System Scope dapat menghasilkan perbedaan peningkatan yang besar pada aspek pemodelan dan pengamatan tak langsung dan tidak menghasilkan perbedaan peningkatan yang besar pada aspek kesadaran tentang skala dan hukum sebab akibat. Berdasarkan hasil tersebut, peneliti dapat merekomendasikan aplikasi Solar System Scope sebagai media pembelajaran yang dapat meningkatkan keterampilan generik sains pada aspek pemodelan dan pengamatan tak langsung pada materi tata surya untuk siswa SMP.

\section{Tanggapan Siswa Terhadap Penggunaan Aplikasi Solar System Scope}

Pada pelaksanaannya, seluruh siswa pada kelas eksperimen telah memiliki pengalaman untuk mengoperasikan aplikasi Solar System Scope pada gawai masingmasing. Setidaknya terdapat satu buah gawai pada setiap kelompok yang dapat digunakan untuk mengakses aplikasi Solar System Scope. Sehingga selama proses pembelajaran, siswa di kelas eksperimen dapat menggunakan aplikasi dengan baik. Siswa juga terlihat antusias ketika dipersilahkan untuk menggunakan gawai pada proses pembelajaran. Meskipun demikian, tanggapan siswa terhadap penggunaan aplikasi ini juga sangat penting untuk diketahui sehingga peneliti menginstruksikan siswa untuk mengisi angket setelah kegiatan pembelajaran selesai. Angket ini juga bertujuan untuk mengetahui ketertarikan siswa terhadap aplikasi Solar System Scope. Angket yang diberikan terdiri dari 13 pernyataan dengan 4 pilihan tanggapan, yaitu sangat setuju, setuju, tidak setuju, dan sangat tidak setuju. Rekapitulasi tanggapan siswa mengenai penggunaan aplikasi Solar System Scope pada pembelajaran tata surya dapat dijelaskan melalui Tabel 5.

Tabel 5. Rekapitulasi Tanggapan Siswa terhadap Penggunaan Aplikasi Solar System Scope

\begin{tabular}{clcc}
\hline No. & \multicolumn{1}{c}{ Pernyataan } & Persentase & $\begin{array}{c}\text { Tingkat } \\
\text { Persetujuan }\end{array}$ \\
\hline 1 & $\begin{array}{l}\text { Saya bisa lebih mengerti suatu materi pelajaran jika dijelaskan } \\
\text { menggunakan gambar. }\end{array}$ & $77 \%$ & Kuat \\
\hline 2 & $\begin{array}{l}\text { Saya bisa lebih mengerti suatu materi pelajaran jika dijelaskan } \\
\text { menggunakan video. }\end{array}$ & $85 \%$ & Kuat \\
\hline
\end{tabular}




\begin{tabular}{clcc}
\hline No. & \multicolumn{1}{c}{ Pernyataan } & Persentase & $\begin{array}{c}\text { Tingkat } \\
\text { Persetujuan }\end{array}$ \\
\hline 3 & $\begin{array}{l}\text { Saya bisa lebih mengerti suatu materi pelajaran jika dijelaskan } \\
\text { menggunakan audio. }\end{array}$ & $66 \%$ & Kuat \\
\hline 4 & $\begin{array}{l}\text { Saya bisa lebih mengerti suatu materi pelajaran jika dijelaskan } \\
\text { menggunakan simulasi. }\end{array}$ & $83 \%$ & Sangat Kuat \\
\hline 5 & $\begin{array}{l}\text { Saya bisa lebih mengerti suatu materi pelajaran jika dijelaskan } \\
\text { menggunakan animasi. }\end{array}$ & $81 \%$ & Sangat Kuat \\
\hline 6 & $\begin{array}{l}\text { Saya tertarik dengan hal-hal yang berhubungan dengan } \\
\text { antariksa. }\end{array}$ & $78 \%$ & Kuat \\
\hline 7 & Saya percaya diri dengan hasil ujian pada materi tata surya. & $76 \%$ & Kuat \\
\hline 8 & Saya dapat mengoprasikan gawai dengan baik. & $71 \%$ & Kuat \\
\hline 10 & Saya menggunakan gawai setiap hari. & $\begin{array}{l}\text { Saya berharap dapat lebih sering menggunakan gawai dalam } \\
\text { proses pembelajaran di kelas. }\end{array}$ \\
\hline 11 & $\begin{array}{l}\text { Saya lebih tertarik untuk mempelajari karakteristik benda } \\
\text { langit setelah menggunakan aplikasi Solar System Scope. }\end{array}$ & $81 \%$ & Sangat Kuat \\
\hline 12 & $\begin{array}{l}\text { Saya lebih tertarik untuk melakukan pengamatan langit setelah } \\
\text { menggunakan aplikasi Solar System Scope. }\end{array}$ & $83 \%$ & Sangat Kuat \\
\hline 13 & $\begin{array}{l}\text { Saya lebih mengerti materi tata surya setelah pembelajaran } \\
\text { menggunakan aplikasi Solar System Scope. }\end{array}$ & $86 \%$ & Sangat Kuat \\
\hline
\end{tabular}

Berdasarkan hasil tersebut, siswa mengemukakan bahwa video merupakan media pembelajaran yang paling mampu meningkatkan pemahaman siswa mengenai suatu materi dibandingkan dengan media lainnya, yaitu gambar, audio, simulasi dan animasi dengan tingkat persetujuan kuat sebesar 85\%. Gawai sebagai media pembelajaran juga sangat diminati siswa dengan tingkat persetujuan sebesar $81 \%$. Hal ini didukung dengan $81 \%$ siswa menyatakan dapat mengoperasikan gawai dengan baik. Sehingga penggunaan aplikasi Solar System Scope yang terpasang pada gawai dan diterapkan di kelas dapat terlaksana. Pernyataan ini didukung dengan hasil angket yang menyatakan bahwa siswa tertarik mempelajari karakteristik benda langit dengan tingkat persetujuan $87 \%$.

Respon siswa terkait penggunaan aplikasi Solar System Scope sangat baik. Terbukti dari semua pernyataan terkait aplikasi Solar System Scope mendapat tingkat persetujuan sangat kuat dari siswa. Siswa menyatakan bahwa setelah menggunakan aplikasi Solar System Scope, mereka lebih tertarik untuk mempelajari karakteristik benda langit, lebih tertarik untuk melakukan pengamatan langit, serta lebih mengerti materi tata surya.

\section{KESIMPULAN}

Berdasarkan penelitian yang telah dilakukan di salah satu SMP Negeri di Kota Bandung dengan judul penelitian "Peningkatan Keterampilan Generik Sains pada Materi Tata Surya melalui Pembelajaran berbantuan Aplikasi Solar System Scope untuk Siswa SMP" dapat diperoleh kesimpulan bahwa terdapat perbedaan peningkatan keterampilan generik sains yang signifikan antara kelas eksperimen dengan kelas kontrol setelah diterapkannya pembelajaran berbantuan aplikasi Solar System Scope.

Hasil tes menunjukkan bahwa kelas eksperimen dan kontrol mengalami peningkatan keterampilan generik sains secara keseluruhan. Namun, peningkatan yang dialami kelas eksperimen lebih besar dibandingkan dengan kelas kontrol. Pemodelan merupakan aspek yang memiliki peningkatan paling tinggi dari seluruh data yang ada. Sementara itu, keterampilan generik sains hukum sebab akibat mengalami peningkatan dengan $N$-gain paling rendah dibandingkan tiga aspek lainnya. Kelas eksperimen mengalami peningkatan yang lebih tinggi dibandingkan kelas kontrol pada aspek pemodelan, pengamatan tak langsung, serta hukum sebab akibat. Namun, pada aspek kesadaran 
tentang skala, peningkatan yang dialami kelas kontrol lebih besar dibandingkan dengan kelas eksperimen.

Dari empat aspek keterampilan generik sains yang diujikan, pemodelan dan pengamatan tak langsung merupakan aspek yang memiliki perbedaan peningkatan yang besar antara kelas eksperimen dan kontrol. Sedangkan perbedaan peningkatan pada aspek kesadaran tentang skala dan hukum sebab akibat tidak terlalu besar. Artinya, aplikasi Solar System Scope sangat sesuai untuk digunakan dalam melatihkan keterampilan generik sains aspek pemodelan dan pengamatan tak langsung pada materi tata surya SMP.

Penggunaan aplikasi Solar System Scope juga didukung oleh pernyataan siswa terkait ketertarikannya pada aplikasi ini. Siswa menyatakan lebih tertarik belajar tata surya setelah diterapkannya pembelajaran berbantuan aplikasi Solar System Scope. Pernyataan ini didukung dengan banyaknya siswa yang menyatakan mampu menggunakan gawai dengan baik karena mayoritas siswa menggunakan gawai setiap hari.

\section{DAFTAR PUSTAKA}

Arikunto, Suharsimi. (2009). Dasar-dasar Evaluasi Pendidikan. Jakarta: Bumi Aksara.

Arikunto, Suharsimi. (2010). Prosedur Penelitian Suatu Pendekatan Praktik. Jakarta: Rineka Cipta.

Bhakti, S.S. dkk., (2017). "Developing Multiple-Choices Tes Items As Tools For Measuring The Scientific-Generic Skills On Solar System". AIP Conference Proceedings. AIP Publishing.

Bhakti, S.S. (2017). Peningkatan Keterampilan Generik Sains dan Berpikir Kritis dalam Pembelajaran IPA Menggunakan $\mathrm{MBI}_{2}$ pada Materi Tata Surya untuk Siswa SMP. Skripsi pada Jurusan Pendidikan Fisika UPI Bandung: tidak diterbitkan.

Brotosiswoyo, Suprapto. (2000). Hakikat Pembelajaran MIPA di Perguruan Tinggi. Jakarta: PAU-PPAI-UT.
Chen et al. (2012). "Effects of Presentation Mode on Mobile Language Learning: A Performance Efficiency Perspective". Australias Journal of Education and Technology.

Chen dan Pei-Hsuan Lin. (2014). "Development and evaluation of a context-aware ubiquitous learning environment for astronomy education". Interactive Learning Environments.

Cole, Merryn dkk. (2015). "Student Moon Observations and Spatial-Scientific Reasoning". International Journal of Science Education.

Delgado, Cesar. (2014). "Navigating Tension Between Conceptual and Metaconceptual Goals in the Use of Models". Journal of Science Education and Technology.

Farid, Miftah dan Leny. (2016). "Pengaruh Model Pembelajaran Problem Solving berbantuan Multimedia Interaktif tergadap Keterampilan Generik Sains dan Hasil Belajar Siswa pada Materi Hidrolisis Garam". Jurnal Inovasi Pendidikan Sains.

Gunawan. (2008). "Pembelajaran Berbasis Multimedia Interaktif untuk Meningkatkan Keterampilan Generik Sains Calon Guru Fisika". Jurnal Pijar MIPA.

Hake, Richard. (1998). "InteractiveEngagement Vs Traditional Methods: A Six-Thousand Student Survey of Mechanics Test Data for Introductory Physics Courses". American Journal of Physics.

Harbeck dan Johnson. Earth and Space Science. USA: Department of Health, Education, and Welfare.

Harrison dan Treagust. (2000). "A Typology of School Science Models". International Journal of Science Education.

Hidayat, Bambang dkk. (1976). Bumi dan Antariksa untuk SMP Kelas VII. Jakarta: Balai Pustaka.

Hochberg, Katrin et al. (2018). "Using Smartphones as Experimental ToolsEffects on Interest, Curiosity, and Learning in Physics Education". Journal of Science Education and Technology.

INOVE (2017). Solar System Scope. [Online]. Diakses di https://www.solarsystemscope.com/. 
Jing. (2013). "Elementary School Teachers' Knowledge of Model Functions and Modeling Processes: A Comparison of Science and Non-science Majors". International Journal of Science and Mathematics Education.

Johnson, dkk. (2002). "Encouraging Generic Skills in Science Courses". Electronic Journal of Biotechnology. Chile. [Online]. Diakses http://www.ejbiotechnology.info/.

Kementerian Pendidikan dan Kebudayaan. (2017). Silabus Mata Pelajaran Sekolah Menengah Pertama/Madrasah Tsanawiyah (SMP/MTs) Mata Pelajaran Ilmu Pengetahuan Alam. Jakarta.

Khabibah et al. (2017). "The Analysis of Generic Science Skills of High School Students". Advences in Social Science, Education and Humanities Research.

Lepp et al. (2014). "The Relationship Between Cell Phone Use, Academic Performance, Anxiety, and Satisfaction with Life in College Students". Computers in Human Behavior.

Margono. (2009). Metodologi Penelitian Pendidikan. Jakarta: Rineka Cipta.

Muslim. (2017). Materi Kuliah Evaluasi Pendidikan Fisika; Analisis Tes. Departemen Pendidikan Fisika FPMIPA UPI.

National Centre for Vocational Education Research. (2003). "Defining Generic Skills: At a Glance". [Online]. Diakses di https://www.ncver.edu.au.

National Research Council (2012). “A Framework For K-12 Science Education: Practices, Crosscutting Concepts, and Core Ideas". National Academies Press, Washington.

Nurjannah, Fitri. (2014). Analisis Kemampuan Generik Siswa Melalui Kegiatan Praktikum Fotosintesis. Skripsi. Tidak diterbitkan. Jakarta: UIN Syarif Hidayatullah.

Partnership for 21 st Century Learning. (2015). "P21 Freamework Definitions". [Online]. Diakses di http://www.p21.org/our-work/p21framework.

Peraturan Pemerintah Republik Indonesia Nomor 19 Tahun 2005 tentang Standar Nasional Pendidikan.
Permendikbud Nomor 20 Tahun 2016 tentang Standar Kompetensi Lulusan Pendidikan Dasar dan Menengah.

Permendikbud Nomor 21 Tahun 2016 tentang Standar Isi Pendidikan Dasar dan Menengah.

Permendikbud Nomor 22 Tahun 2016 tentang Standar Proses Pendidikan Dasar dan Menengah.

Permendikbud Nomor 23 Tahun 2016 tentang Standar Penilaian Pendidikan.

Permendikbud Nomor 24 Tahun 2016 tentang Kompetensi Inti dan Kompetensi Dasar Pelajaran pada Kurikulum 2013 pada Pendidikan Dasar dan Pendidikan Menengah.

Price, Aaron dkk. (2015). "Comparing Shortand Long-Term Learning Effects Between Stereoscopic and TwoDimensional Film at a Planetarium". Science Education.

Purba, Siska Wati Dewi dan Wu-Yuin Hwang. (2017). "Investigation of Learning Behaviors and Achievement of Vocational High School Students Using an Ubiquitous Physics Tablet PC App". Journal of Science Education and Technology.

Riduwan. (2007). Skala Pengukuran Variabel-variabel Penelitian. Bandung: Alfabeta.

Saprudin, et al. (2010). "Developing Generic Science Skills of Prospective Teacher Through Offline and Online Interactive Multimedia in Physics Learning". Proceedings of The 4th International Conference on Teacher Education; Join Conference UPI \& UPSI.

Saruman, Surya. (2016). Pengembangan Bahan Ajar Berbasis Aplikasi Netsupport School dalam Meningkatkan Hasil Belajar Siswa SMA Negeri 6 Palopo. Makassar: Pascasarjana Universitas Negeri Makassar.

Siahaan, P et al. (2010). Bahan Ajar Statistika Dasar. Bandung: Jurusan Pendidikan Fisika, FPMIPA UPI.

Siahaan, P et al. (2017). "Improving Students' Science Process Skills through Simple Computer Simulations on Linear Motion Conceptions. IOP Conf. Series: Journal of Physics.

Skinner, Brian. (1959). The Solar System and It's Strange Objects. California. 
Soepeno, Bambang. (2002). Statistika Terapan dalam Ilmu-ilmu Sosial dan Pendidikan. Jakarta: Rineka Cipta.

Soland et al. (2013). Measuring 21 ${ }^{\text {st }}$ Century Competencies - Guidance for Educators. RAND Corporation. [Online]. Diakses di https://www.rand.org.

Sudarmin. (2007). Pembekalan Keterampilan Generik Kimia Organik bagi Calon Guru. Disertasi. Bandung: SPs UPI.

Sudarmin. (2009). "Meningkatkan Kemampuan Berpikir Mahasiswa Melalui Pembelajaran Kimia Terintegrasi Kemampuan Generik Sains pada Materi Kesetimbangan Kimia". Prosiding seminar nasional kimia dan Pendidikan kimia II (SN-KPK II) UNS. Semarang.

Sugiyono. (2012). Metode Penelitian Kuantitatif Kualitatif dan $R \& D$. Bandung: Alfabeta.

Sundayana, Rostina. (2015). Statistika Penelitian Pendidikan. Bandung: Alfabeta.

Tawil, M. dan Liliasari. (2014). Keterampilan-keterampilan Sains dan Implementasinya dalam Pembelajaran IPA. Makassar: Badan Penerbit Universitas Negeri Makassar.

Testa, Italo dan Silvia Galano. (2015). "Development and Validation of a Learning Progression for Change of Seasons, Solar and Lunar Eclipses, and Moon Phases". Physics Education Research.
Tim Abdi Guru. (2016). IPA Terpadu untuk SMP/MTs Kelas VII. Jakarta: Penerbit Erlangga.

Tjasyono, Bayong. (2013). Ilmu Kebumian dan Antariksa. Bandung: Remaja Rosdakarya.

Turk, Cumhur. (2014). "The Effect of Planetariums on Teaching Specific Astronomy Concepts". Journal of Science Education and Technology.

Weintrop et al. (2015). "Defining Computational Thinking for Mathematics and Science Classrooms". Journal of Science Education and Technology.

Widodo, Wahono et al. (2010). "Integrasi Multimedia Interaktif, Kerja Kolaboratif, dan Berpikir Reflektif dalam Perkuliahan Fisika Dasar untuk Meningkatkan Keterampilan Generik Sains Calon Guru SMK Tata Boga". Jurnal Pendidikan dan Pembelajaran.

Wood, John. (1979). The Solar System. New Jersey: Englewood Cliffs.

Wooten, Michelle et al. (2014). "Comparison of Performance on Multiple-Choice Questions and Open-Ended Questions in an Introductory Astronomy Laboratory". Physics Education Research.

Yulianti et al. (2016). "Peningkatan Keterampilan Generik Sains dan Penguasaan Konsep Melalui Laboratorium Virtual Berbasis Inkuiri”. Jurnal Pendidikan Sains Indonesia. 